\title{
PELATIHAN KOMPUTER SEBAGAI BENTUK PENGEMBANGAN NILAI-NILAI KARAKTER DALAM BIDANG PENDIDIKAN
}

\author{
(Computer Training as the Form of Character Value Development in Education Field)
}

\author{
Supardi, Nurul Hikmah Kartini dan Agustina Fatmawati \\ Universitas Muhammadiyah Palangkaraya \\ JI. RTA Milono Km.1,5 Palangka Raya, Kalimantan Tengah 73111 \\ e-mail : supardi242@gmail.com \\ nurul.kartini@umpalangkaraya.ac.id \\ Agustinafatmawatihadi@gmail.com
}

Program Studi Pendidikan Guru Sekolah Dasar (PGSD) Fakultas Keguruan dan IImu Pendidikan

\begin{abstract}
The result of the analysis of the studyshows the lack of educational condition related to Information Technology (IT) especially for orphanage children. Community service activities aim to provide computer training as a form of character development in the field of education.

The subjects of community service activities are the children at the Mujahidin Orphanage in Anjir Serapat Village, Kapuas Timur Sub-District, Kapuas District, with 11 members. Training activities are supported by lecture methods, frequently asked questions and direct practice of using computer applications with the help of training modules provided to the participants as a tool in practice.

The results showed that computer training can give knowledge and understanding for orphaned children in computer skills in the mastery of Microsoft Word, Microsoft Excel, and Microsoft Powerpoint and can foster the values of educational characters in themselves such as curiosity, creative, hard work, and communicative.
\end{abstract}

Keywords: training, value development, character value, education

\section{Abstrak}

Hasil analisis situasi menunjukkan minimnya kondisi pendidikan yang berkaitan dengan Teknologi Informasi (TI) khususnya bagi anak-anak panti asuhan. Kegiatan pengabdian kepada masyarakat ini bertujuan untuk memberikan pelatihan komputer sebagai bentuk pengembangan nilainilai karakter dalam bidang pendidikan.

Subjek kegiatan pengabdian kepada masyarakat adalah anak-anak di Panti Asuhan Mujahidin di Desa Anjir Serapat Kecamatan Kapuas Timur Kabupaten Kapuas yang berjumlah 11 orang binaan. Kegiatan pelatihan ditunjang dengan metode ceramah, tanya jawab dan praktek langsung penggunaan aplikasi komputer dengan bantuan modul pelatihan yang diberikan kepada peserta sebagai alat bantu dalam kegiatan praktek.

Hasil kegiatan menunjukkan bahwa pelatihan komputer dapat memberikan pengetahuan dan pemahaman bagi anak-anak panti asuhan dalam keterampilan komputer dalam penguasaan Microsoft Word, Microsoft Excel, dan Microsoft Powerpoint serta dapat menumbuhkan nilai-nilai karakter pendidikan pada diri mereka diantaranya berupa rasa ingin tahu, kreatif, kerja keras, dan komunikatif.

Kata kunci : pelatihan, pengembangan nilai, nilai karakter, pendidikan 


\section{PENDAHULUAN}

\section{Analisis Situasi}

Kabupaten Kapuas adalah salah satu kabupaten di Provinsi Kalimantan Tengah. Ibu kota kabupaten ini terletak di Kuala Kapuas. Wilayah ini memiliki luas $14.999 \mathrm{~km}^{2}$ atau 1.499.900 ha dengan tingkat kepadatan penduduk 21,97 jiwa $/ \mathrm{km}^{2}$. Berdasarkan hasil Sensus Penduduk Indonesia 2010, kabupaten ini berpenduduk 329.646 jiwa dengan klasifikasi 168.139 laki-laki dan 161.507 perempuan. Kapuas Timur merupakan salah satu kecamatan di Kabupaten Kapuas. Kecamatan ini merupakan jalan keluar Provinsi Kalimantan Tengah menuju provinsi Kalimantan Selatan dengan akses melalui jalan Trans Kalimantan. Kecamatan ini terdiri dari 7 desa, salah satunya adalah Desa Anjir Serapat, yang menjadi lokasi dalam program pengabdian kepada masyarakat.

Desa Anjir Serapat dipilih sebagai lokasi dalam program pengabdian masyarakat dengan pertimbangan kondisi pendidikan anak didiknya yang belum memenuhi Undang-Undang Nomor 20 Tahun 2003 tentang Sistem Pendidikan Nasional yang menyebutkan hak peserta didik yaitu: (1) Mendapatkan pendidikan agama sesuai dengan agama yang dianutnya dan diajarkan oleh pendidik yang seagama, (2) Mendapatkan pelayanan pendidikan sesuai dengan bakat, minat, dan kemampuannya, (3) Mendapatkan beasiswa bagi yang berprestasi yang orang tuanya tidak mampu membiayai pendidikannya, (4) Mendapatkan biaya pendidikan bagi mereka yang orang tuanya tidak mampu membiayai pendidikannya, (5) Pindah ke program pendidikan pada jalur dan satuan pendidikan lain yang setara, dan (6) Menyelesaikan program pendidikan sesuai dengan kecepatan belajar masing-masing dan tidak menyimpang dari ketentuan batas waktu yang ditetapkan. Guna mencapai hal tersebut, maka diperlukan peran serta masyarakat dalam penyelenggaraan dan pengendalian mutu pelayanan pendidikan di Desa Anjir Serapat, salah satunya melalui kegiatan pengabdian kepada masyarakat.

Hasil analisis situasi menunjukkan minimnya kondisi pendidikan yang berkaitan dengan Teknologi Informasi (TI), khususnya bagi anak-anak Panti Asuhan Mujahidin di Desa Anjir Serapat. Padahal perkembangan teknologi sekarang ini, terutama teknologi komputer sudah sangat maju. Selain dapat mengakses informasi dari segala penjuru dunia, komputer juga dapat digunakan untuk membantu para pendidik untuk mengajar dan menyajikan pelajaran yang menarik dan kreatif sehingga peserta didik merasa nyaman dengan pengajaran yang telah diberikan oleh pendidik. Komputer juga dapat membantu peserta didik untuk membuat tugas dan karya ilmiah yang baik dan menarik. Menurut Sudjana \& Rivai (1989) ada beberapa model pembelajaran dengan komputer, yaitu model latihan dan praktek (drill and practice), model tutorial (tutorials), model penemuan (problem solving), model simulasi (simulations), dan model permainan (game). Model pembelajaran ini dapat digunakan pendidik dalam kegiatan pembelajaran agar pembelajaran lebih menarik sehingga dapat membantu peserta didik untuk mengembangkan pengetahuan mereka. Gagne \& Briggs dalam Rosenberg (2000) menambahkan komputer juga dapat 
digunakan sebagai media pembelajaran karena memiliki kelebihan dari media yang lain dan memiliki fungsi yaitu (a) Sebagai hubungan interaktif, dimana komputer dapat menjembatani hubungan komunikasi antara dua orang atau lebih. Komputer dapat memunculkan ide-ide atau wacana baru dan meningkatkan minat terhadap media. (b) Pengulangan, dimana pengguna komputer terutama peserta didik dan guru dapat mengulang materi atau bahan ajar dengan metode yang menarik yang telah disediakan komputer seperti musik, video, atau microsoft office. (c) Feedback and Reward, dengan komputer guru atau pendidik dapat memberikan saran atau perbaikan dan tentu saja pujian kepada mahasiswa yang dapat menyelesaikan tugasnya dengan baik. Saran dan pujian ini dapat disampaikan secara online dan seketika sehingga peserta didik yang lain dapat mengetahui saran, perbaikan dan pujian tersebut yang tentunya juga dapat menjadi motivasi untuk meningkatkan potensi diri terutama dalam pembelajaran. Pentingnya pendidikan Teknologi dan Informasi (TI) saat ini yang berbanding terbalik dengan kondisi pendidikan anak-anak panti asuhan terkait TI, menjadi perhatian bagi praktisi pendidikan untuk menjadikan anak-anak tersebut sebagai sasaran dalam kegiatan pengabdian kepada masyarakat.

\section{Permasalahan}

Hasil analisis situasi menunjukkan bahwa di masyarakat anak-anak terdapat kondisi minimnya dukungan pelaksanaan pendidikan yang berkaitan dengan Teknologi Informasi (TI) khususnya bagi anak-anak panti asuhan. Pelatihan beberapa aplikasi komputer kepada anak-anak menjadi perlu dan penting dilakukan sebagai bentuk peningkatan pengetahuan dalam bidang teknologi dan informasi sekaligus diharapkan sebagai pengembangan nilai-nilai karakter anak-anak.

\section{Tujuan}

Kegiatan pengabdian kepada masyarakat ini bertujuan untuk memberikan pelatihan beberapa aplikasi komputer kepada anak-anak sebagai bentuk peningkatan pengetahuan dalam bidang teknologi dan informasi serta pengembangan nilai-nilai karakter anak-anak dalam bidang pendidikan.

\section{METODE PELAKSANAAN}

\section{Waktu dan Tempat}

Kegiatan pengabdian kepada masyarakat ini pendampingannya dilaksanakan selama satu bulan, dengan beberapa pertemuan. Lokasi pelaksanaan pengabdian kepada masyarakat ini dipusatkan di Panti Asuhan Mujahidin di Desa Anjir Serapat Kecamatan Kapuas Timur Kabupaten Kapuas Provinsi Kalimantan Tengah.

\section{Sasaran Kegiatan}

Masyarakat sasaran dalam kegiatan pengabdian kepada masyarakat ini adalah anakanak di Panti Asuhan Mujahidin di Desa Anjir Serapat Kecamatan Kapuas Timur Kabupaten Kapuas yang berjumlah 11 orang binaan yang rata-rata mereka adalah anak-anak yang berasal dari keluarga miskin sangat layak mendapat perhatian dari segi ekonomi, pendidikan, teknologi, dan segi kehidupan lainnya.

\section{Metode Kegiatan}

Metode yang digunakan dalam kegiatan pengabdian kepada masyarakat ini adalah berupa kegiatan pelatihan yang ditunjang dengan metode 
ceramah, tanya jawab dan praktek langsung penggunaan beberapa aplikasi komputer dengan bantuan modul pelatihan yang diberikan kepada peserta sebagai alat bantu dalam kegiatan praktek. Peserta pelatihan dikelompokkan menjadi 2 (dua) bagian yaitu kelompok tingkat dasar (Kelompok 1) dan kelompok tingkat mahir (Kelompok 2), sehingga aplikasi komputer yang diberikan selama pelatihan dibedakan jenisnya.

\section{Solusi yang Ditawarkan}

Solusi yang ditawarkan akibat kegiatan pengabdian kepada masyarakat ini adalah:

1. Situasi di masyarakat anak-anak terdapat peningkatan dukungan pelaksanaan pendidikan yang berkaitan dengan Teknologi Informasi (TI) khususnya bagi anak-anak panti asuhan.

2. Adanya pelatihan beberapa aplikasi komputer kepada anak-anak menjadi bentuk peningkatan pengetahuan dalam bidang teknologi dan informasi.

3. Adanya pelatihan beberapa aplikasi komputer kepada anak-anak menjadi bentuk yang diharapkan mampu mengembangkan nilai-nilai karakter anak-anak dalam bidang pendidikan.

\section{HASIL DAN PEMBAHASAN}

Kegiatan pengabdian kepada masyarakat tentang pelatihan beberapa aplikasi komputer sebagai bentuk pengembangan nilai-nilai karakter dalam bidang pendidikan diharapkan mampu memberikan pengetahuan dan pemahaman bagi anak-anak panti asuhan dalam keterampilan komputer dan penguasaan Microsoft Word, Microsoft Excel, dan Microsoft Powerpoint, serta dapat menumbuhkan nilai-nilai karakter pada diri mereka. Melalui kegiatan ini, tim akan memberikan materi dari modul dan kiat-kiat untuk mengembangkan keterampilan serta bekal pendidikan yang berbasis teknologi informasi.

Berdasarkan data yang diperoleh melalui pengurus, Panti Asuhan Mujahidin Kuala Kapuas yang berdiri sejak 1 Januari 2015 dan diresmikan oleh Pimpinan Pusat Muhammadiyah ini memiliki anak asuh sebanyak 11 orang dan seluruhnya berjenis kelamin laki-laki. Hasil informasi menunjukkan hanya 4 (empat) anak yang pernah mengoperasikan komputer. Empat anak tersebut duduk di Sekolah Menengah Pertama (SMP), 6 (enam) anak lainnya masih duduk di bangku Sekolah Dasar (SD), sedangkan 1 (satu) anak lainnya masih berada pada usia pra sekolah.

Berdasarkan informasi latar belakang di atas, sebagian besar anak-anak panti asuhan berasal dari keluarga yang memiliki taraf ekonomi rendah, baik disebabkan meninggalnya orangtua ataupun karena menjadi korban perceraian. Faktanya, perceraian dapat menimbulkan problematika kerumahtanggaan seperti persoalan hak pemeliharaan anak, pemberian kasih sayang, pemberian nafkah dan sebagainya. Akibat perceraian juga akan dirasakan oleh anak-anak terutama ketika orang tua mereka menikah lagi dan anak harus dirawat oleh ayah atau ibu tiri. Kasus-kasus semacam ini tentunya memberikan efek psikologis dan memunculkan karakter yang buruk bagi anak apabila tidak diarahkan dengan baik. Guna mengatasi hal ini, maka diperlukan suatu program pelatihan dan pembinaan yang dilakukan sebagai upaya pembentukan karakter anak secara konsisten dan terus menerus bagi masyarakat, keluarga, atau orang tua, terutama anak-anak. 


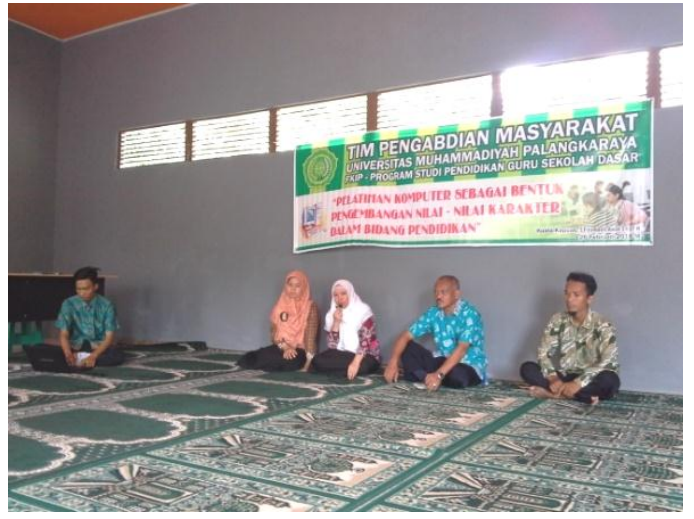

Gambar 1. Acara pembukaan pengabdian kepada masyarakat dalam bentuk pelatihan

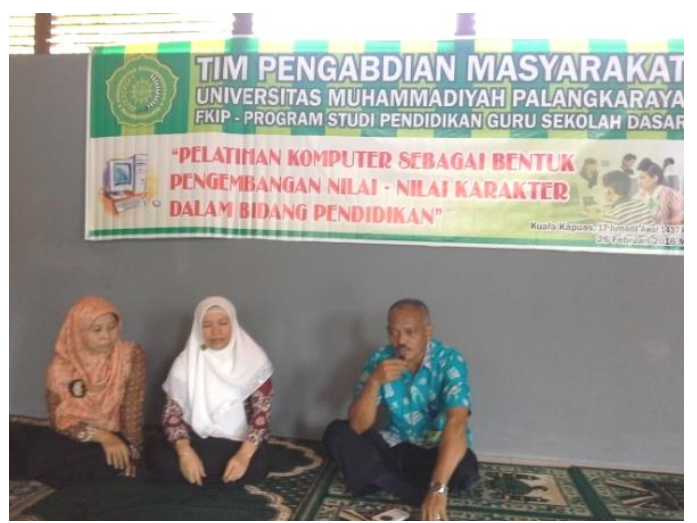

Gambar 2. Sambutan oleh ketua tim pengabdian kepada masyarakat (Drs.Supardi, M.Pd)

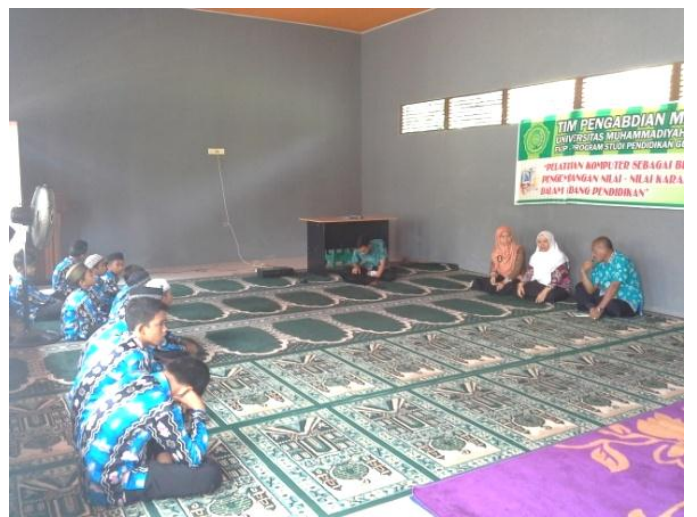

Gambar 3. Lokasi kegiatan pengabdian kepada masyarakat di Aula Panti Asuhan Mujahidin Desa Anjir Serapat Kuala Kapuas, Kabupaten Kapuas
Sebagai bentuk dukungan dan aplikasi nyata dari program tersebut, maka kegiatan yang dilaksanakan oleh tim pengabdian masyarakat lebih ditekankan pada manfaat pelatihan komputer dan pembinaan karakter pada diri anak. Secara teoritis, istilah pelatihan (training) adalah suatu proses dimana orang-orang mencapai kemampuan tertentu untuk membantu pencapaian tujuan (Mathis \& Jackson, 2002). Sikula (1976) mendefinisikan pelatihan sebagai proses pendidikan jangka pendek yang menggunakan prosedur yang sistematis dan terorganisir. Definisi-definisi tersebut menggambarkan bahwa pelatihan merupakan proses membantu peserta untuk memperoleh keterampilan agar dapat mencapai efektivitas dalam melaksanakan tugas tertentu melalui pengembangan proses berpikir, sikap, pengetahuan, kecakapan dan kemampuan.

Sementara karakter menurut Freud (Aqib, 2011) dapat didefinisikan sebagai kumpulan tata nilai yang terwujud dalam suatu sistem daya dorong (daya juang) yang melandasi pemikiran, sikap dan perilaku yang akan ditampilkan secara mantap. Allport dalam Marwanti, 2011 mendefinisikan karakter sebagai suatu organisasi yang dinamis dari sistem psikofisik individu yang menentukan tingkah laku dan pemikiran individu secara khas. Ahli yang lain menambahkan pendidikan karakter adalah pendidikan budi pekerti plus, yaitu yang melibatkan aspek pengetahuan (cognitive), perasaan (feeling), dan tindakan (action). Menurut (Lickona, 1992), tanpa ketiga aspek ini, maka pendidikan karakter tidak akan efektif, dan pelaksanaannya pun harus dilakukan secara sistematis dan berkelanjutan. Dengan pendidikan karakter, seorang anak akan 
menjadi cerdas emosinya. Kecerdasan emosi adalah bekal terpenting dalam mempersiapkan anak menyongsong masa depan, karena dengannya seseorang akan dapat berhasil dalam menghadapi segala macam tantangan, termasuk tantangan untuk berhasil secara akademis.

Kementerian Pendidikan Nasional juga telah merumuskan 18 Nilai Karakter yang perlu ditanamkan dalam diri peserta didik sebagai upaya membangun karakter bangsa, yaitu (1) Religius, yakni ketaatan dan kepatuhan dalam memahami dan melaksanakan ajaran agama (aliran kepercayaan) yang dianut, termasuk dalam hal ini adalah sikap toleran terhadap pelaksanaan ibadah agama (aliran kepercayaan) lain, serta hidup rukun dan berdampingan. (2) Jujur, yakni sikap dan perilaku yang menceminkan kesatuan antara pengetahuan, perkataan, dan perbuatan (mengetahui apa yang benar, mengatakan yang benar, dan melakukan yang benar) sehingga menjadikan orang yang bersangkutan sebagai pribadi yang dapat dipercaya. (3) Toleransi, yakni sikap dan perilaku yang mencerminkan penghargaan terhadap perbedaan agama, aliran kepercayaan, suku, adat, bahasa, ras, etnis, pendapat, dan hal-hal lain yang berbeda dengan dirinya secara sadar dan terbuka, serta dapat hidup tenang di tengah perbedaan tersebut. (4) Disiplin, yakni kebiasaan dan tindakan yang konsisten terhadap segala bentuk peraturan atau tata tertib yang berlaku. (5) Kerja keras, yakni perilaku yang menunjukkan upaya secara sungguh-sungguh (berjuang hingga titik darah penghabisan) dalam menyelesaikan berbagai tugas, permasalahan, pekerjaan, dan lain-lain dengan sebaik-baiknya. (6) Kreatif, yakni sikap dan perilaku yang mencerminkan inovasi dalam berbagai segi dalam memecahkan masalah, sehingga selalu menemukan cara-cara baru, bahkan hasil-hasil baru yang lebih baik dari sebelumnya. (7) Mandiri, yakni sikap dan perilaku yang tidak tergantung pada orang lain dalam menyelesaikan berbagai tugas maupun persoalan. Namun hal ini bukan berarti tidak boleh bekerjasama secara kolaboratif, melainkan tidak boleh melemparkan tugas dan tanggung jawab kepada orang lain. (8) Demokratis, yakni sikap dan cara berpikir yang mencerminkan persamaan hak dan kewajiban secara adil dan merata antara dirinya dengan orang lain. (9) Rasa ingin tahu, yakni cara berpikir, sikap, dan perilaku yang mencerminkan penasaran dan keingintahuan terhadap segala hal yang dilihat, didengar, dan dipelajari secara lebih mendalam. (10) Semangat kebangsaan atau nasionalisme, yakni sikap dan tindakan yang menempatkan kepentingan bangsa dan negara di atas kepentingan pribadi atau individu dan golongan. (11) Cinta tanah air, yakni sikap dan perilaku yang mencerminkan rasa bangga, setia, peduli, dan penghargaan yang tinggi terhadap bahasa, budaya, ekomoni, politik, dan sebagainya, sehingga tidak mudah menerima tawaran bangsa lain yang dapat merugikan bangsa sendiri. (12) Menghargai prestasi, yakni sikap terbuka terhadap prestasi orang lain dan mengakui kekurangan diri sendiri tanpa mengurangi semangat berprestasi yang lebih tinggi. (13) Komunikatif, senang bersahabat atau proaktif, yakni sikap dan tindakan terbuka terhadap orang lain melalui komunikasi yang santun sehingga tercipta kerja sama secara kolaboratif dengan baik. (14) Cinta damai, yakni sikap dan perilaku yang mencerminkan suasana damai, aman, tenang, dan nyaman atas kehadiran 
dirinya dalam komunitas atau masyarakat tertentu. (15) Gemar membaca, yakni kebiasaan dengan tanpa paksaan untuk menyediakan waktu secara khusus guna membaca berbagai informasi, baik buku, jurnal, majalah, koran, dan sebagainya, sehingga menimbulkan kebijakan bagi dirinya. (16) Peduli lingkungan, yakni sikap dan tindakan yang selalu berupaya menjaga dan melestarikan lingkungan sekitar. (17) Peduli sosial, yakni sikap dan perbuatan yang mencerminkan kepedulian terhadap orang lain maupun masyarakat yang membutuhkannya. (18) Tanggung jawab, yakni sikap dan perilaku seseorang dalam melaksanakan tugas dan kewajibannya, baik yang berkaitan dengan diri sendiri, sosial, masyarakat, bangsa, negara, maupun agama. Uraian tersebut menunjukkan bahwa pendidikan karakter sangat perlu ditanamkan sedini mungkin untuk mengantisipasi persoalan di masa depan yang semakin kompleks seperti semakin rendahnya perhatian dan kepedulian anak terhadap lingkungan sekitar, tidak memiliki tanggungjawab, rendahnya kepercayaan diri, dan lain-lain.

Pelaksanaan kegiatan program pengabdian kepada masyarakat dalam bentuk pelatihan komputer, baik proses maupun hasil dapat dikatakan berhasil dengan baik. Kegiatan pelatihan komputer ini telah diikuti oleh 11 peserta dari Panti Asuhan Mujahidin. Secara prosedur, kegiatan pelatihan dimulai dengan pembagian kelompok berdasarkan pengetahuan awal yang dimiliki. Kelompok 1 berisi anak-anak dengan keterampilan dasar yang diberikan pelatihan berupa pengenalan komputer secara umum dan penguasaan Microsoft Word. Sedangkan kelompok 2 terdiri dari anak-anak yang duduk di bangku SMP, diberikan keterampilan lanjutan Microsoft Excel dan Microsoft Powerpoint. Sambil berjalannya pemberian materi melalui modul dan praktek langsung, kegiatan juga diselingi tanya jawab sehingga penguasaan materi dirasa lebih tepat sasaran.

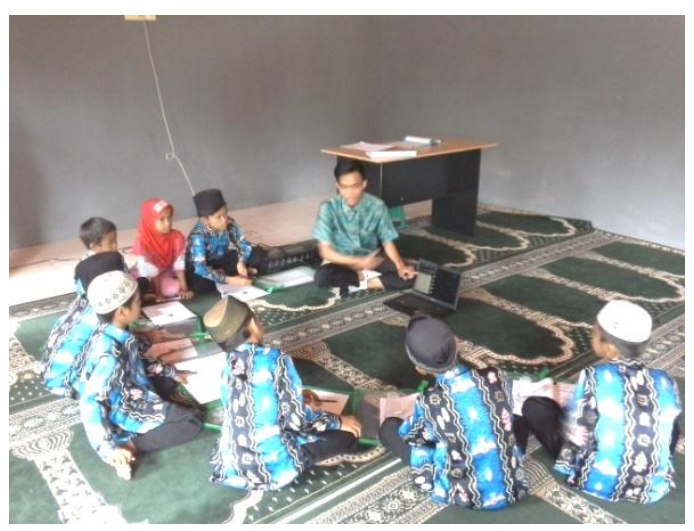

Gambar 4. Suasana Kelompok 1 (tingkat dasar) mendapatkan pelatihan pada materi Microsoft Word

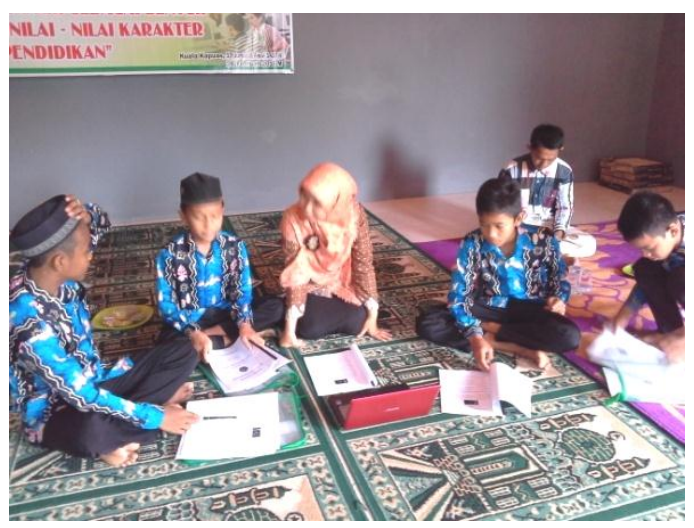

Gambar 5. Suasana Kelompok 2 (tingkat mahir) mendapatkan pelatihan pada materi Ms. Excel dan Ms. Powerpoint 


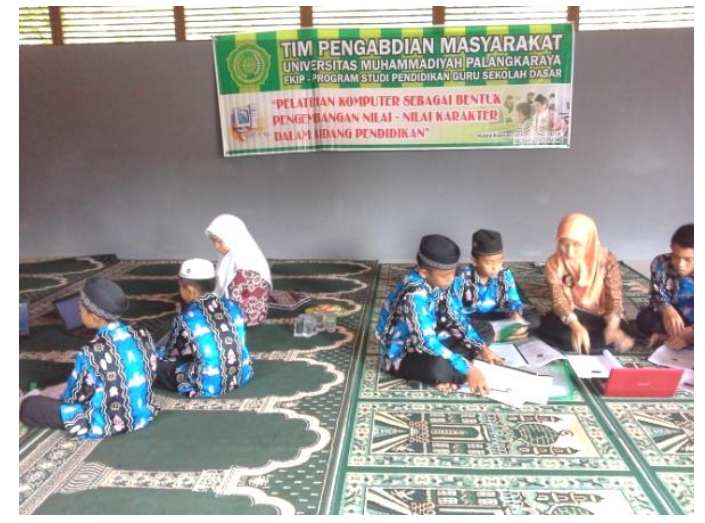

Gambar 6. Anggota tim pengabdian kepada masyarakat memberikan materi pelatihan sekaligus praktek penggunaan aplikasi Microsoft Word, Microsoft Excel dan Microsoft Powerpoint

Beberapa temuan yang diperoleh selama pelaksanaan kegiatan antara lain sebagai berikut: (1) tingkat keberhasilan penguasaan komputer yang diajarkan di Kelompok 1 maupun Kelompok 2 sudah tergolong baik. (2) Kendala-kendala yang dihadapi oleh tim dalam pelaksanaan kegiatan yaitu berupa efektivitas waktu, kekakuan anakanak dalam pengoperasian laptop tanpa menggunakan mouse, dan belum terlalu lancarnya anak-anak Kelompok 1 dalam membaca isi modul yang diberikan sehingga tim menggunakan metode berupa penguatan pada simbol-simbol yang terdapat pada piranti keras tersebut. (3) Antusiasme dan respon positif yang diberikan oleh anak-anak selama pelaksanaan kegiatan. Nur (2011) menyatakan bahwa respon yang baik dapat dihasilkan melalui kegiatan yang menarik, merangsang dan menyenangkan bagi peserta didik.

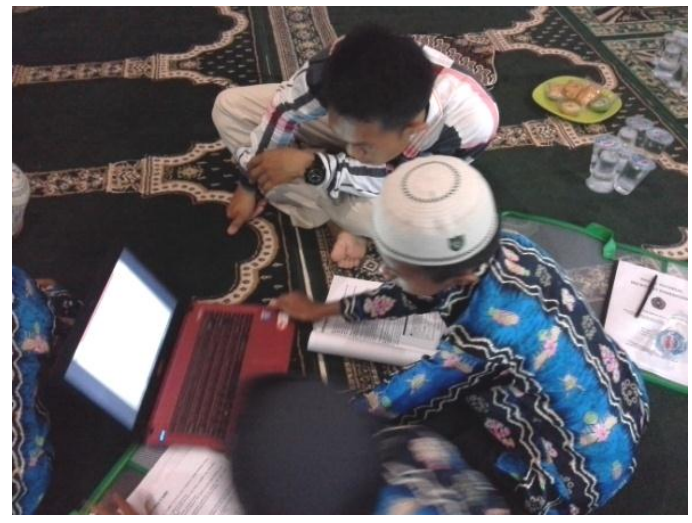

Gambar 7. Peserta pelatihan tingkat dasar antusias mempraktekkan materi Microsoft Word dengan bekerjasama dan berkomunikasi dengan rekannya

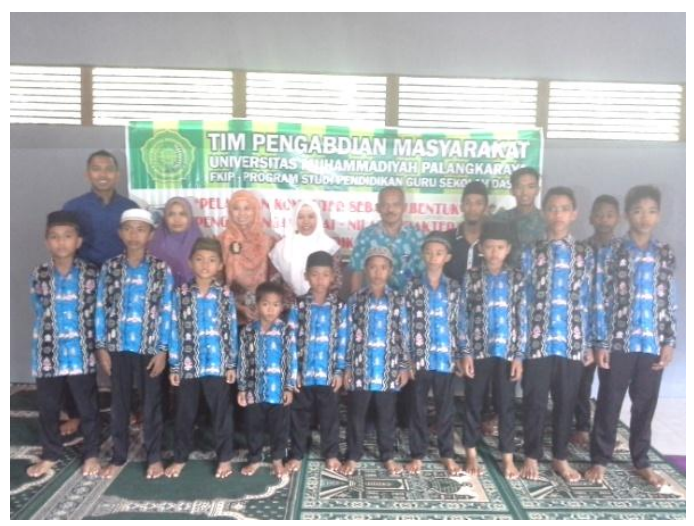

Gambar 8. Foto bersama setelah kegiatan Pelatihan Komputer (belakang: Eko, Ibu Erna, Agustina Fatmawati, Nurul Hikmah Kartini, Supardi, Ust. Arif, Sutrisno, Radian, depan: Hadri, Ridho, Nanda, Muhamad, Hurman, Faisal, Humaidi, Riyan, Ahmad, Ramaji).

Hasil kegiatan pelatihan ini menunjukkan bahwa pelatihan komputer dapat memberikan pengetahuan dan pemahaman bagi anak-anak panti asuhan dalam keterampilan komputer dan penguasaan Microsoft Word, Microsoft Excel, dan Microsoft Powerpoint, serta dapat menumbuhkan nilai-nilai karakter pada diri mereka, seperti rasa ingin tahu, kreatif, kerja keras, dan komunikatif. Hal demikian senada dengan arah Kementerian 
Pendidikan Nasional R.I. yang menyatakan bahwa pendidikan dituntut untuk dapat merubah peserta didik ke arah yang lebih baik melalui penanaman 18 nilai karakter dalam diri peserta didik sebagai upaya membangun karakter bangsa, yaitu religius, jujur, toleransi, disiplin, kerja keras, kreatif, mandiri, demokratis, rasa ingin tau, semangat berkebangsaan atau nasionalisme, cinta tanah air, menghargai prestasi, komunikatif, cinta damai, gemar membaca, peduli lingkungan, peduli sosial, dan tanggung jawab. Diharapkan setelah mengikuti pelatihan ini, anak-anak tersebut akan mampu menggunakan pengetahuan dan keterampilan komputer yang telah diberikan sebagai bahan untuk menunjang pembelajaran mereka di sekolah ataupun sebagai bekal masa depannya.

\section{SIMPULAN DAN SARAN}

\section{Simpulan}

Kegiatan pengabdian kepada masyarakat ini menghasilkan simpulan yaitu:

1. Pelatihan komputer yang dilaksanakan dapat memberikan pengetahuan dan pemahaman bagi anak-anak panti asuhan dalam keterampilan komputer dan penguasaan Microsoft Word, Microsoft Excel, dan Microsoft Power Point, serta dapat menumbuhkan nilainilai karakter pada diri mereka, seperti rasa ingin tahu, kreatif, kerja keras, dan komunikatif.

2. Pelaksanaan kegiatan pelatihan ini memiliki tingkat keberhasilan yang tergolong baik yang ditunjukkan oleh penguasaan pengetahuan dan keterampilan komputer yang diajarkan di Kelompok 1 maupun di Kelompok 2.
3. Kendala dalam kegiatan ini yaitu masalah kekakuan anak-anak dalam pengoperasian laptop tanpa menggunakan mouse dan belum terlalu lancarnya anak-anak di Kelompok 1 dalam membaca modul yang diberikan.

4. Penggunaan metode dengan mengingat symbol (ikon), sebagai jalan keluar bagi anakanak yang kesulitan membaca dan memahami modul (bahan ajar).

\section{Saran}

Setelah kegiatan pengabdian kepada masyarakat ini menghasilkan saran berupa perlu dan pentingnya diadakan kegiatan pelatihan lanjutan yang berkesinambungan untuk mewujudkan sebuah Desa Binaan yang dituangkan dalam Rencana Strategis Pengabdian Kepada Masyarakat.

\section{UCAPAN TERIMA KASIH}

Ucapan terima kasih disampaikan kepada Universitas Muhammadiyah Palangkaraya yang telah memfasilitasi dan membantu pendanaan pembiayaan kegiatan pengabdian kepada masyarakat pada Tahun Anggaran 2015. Terimakasih juga disampaikan kepada para pihak Pengurus Daerah Muhammadiyah Kapuas, Pengelola Panti Asuhan, Pengasuh dan Ustadz, dan para anak-anak binaan di Panti Asuhan Mujahidin di Desa Anjir Serapat Kecamatan Kapuas Timur Kabupaten Kapuas Provinsi Kalimantan Tengah yang secara aktif berpartisipasi pada pelatihan ini.

\section{DAFTAR PUSTAKA}

Aqib, Z. 2011. Pendidikan Karakter Membangun Perilaku Positif Anak Bangsa. Bandung: CV. YRAMA WIDYA. 
Bernardin, H. J. \& Russell, J. E. A. 1993. Human Resource Management, An Experiential Approach. Mc Graw Hill Inc

Lickona, T. 1992. Educating for Character: How Our Schools Can Teach Respect and Responsibility, 1992, New York: Bantam Books

Mathis, R. L. \& Jackson, J. H. 2002. Manajemen Sumber Daya Manusia Edisi Pertama. Jakarta: Salemba Empat

Narwanti, S. 2011. Pendidikan Karakter (Pengintegrasian 18 Nilai Pembentuk Karakter Dalam Mata Pelajaran). Yogyakarta: Familia.

Nur, M. 2011. Model Pembelajaran Berdasarkan Masalah. Surabaya: Pusat Sains dan Matematika Sekolah UNESA.

Sikula, A.F, 1976, Personel Administration and Human Resources Management, Canada; John Wiley and Sous, Inc.

Sudjana, N \& Rivai, A. 1990. Media Pengajaran. Bandung: Sinar Baru

Undang-Undang R.I. Nomor 20 Tahun 2003 tentang Sistem Pendidikan. 2003. Jakarta: Kementerian Pendidikan dan Kebudayaan R.I. 